\title{
GLOBALIZATION TENDENCIES WITH RESPECT TO THE LANGUAGE
}

\author{
Hanne-Lore Bobáková ${ }^{1}, J_{a n a}$ Hejtmánková ${ }^{2}$ \\ ${ }^{1}$ Slezská univerzita, Obchodně podnikatelská fakulta, Univerzitní nám. 1934/3,73340 Karviná \\ Email:bobakova@opf.slu.cz \\ 2 Slezská univerzita, Obchodně podnikatelská fakulta, Univerzitní nám. 1934/3,733 40 Karviná \\ Email:hejtmankova@opf.slu.cz.
}

\begin{abstract}
The article deals with considerations concerning globalization tendencies, and their impact on the languages, especially the Czech language. It reflects the positive and negative sides of the phenomenon which is becoming a reality in all Europe, and based on the given fact, it tackles the term language internationalization and language "Europeanization". Further it deals with the processes at various levels, namely political, economic, and cultural as well. In the second part an analysis of the globalization impacts on the language is carried out. In relation to it, language internationalization, which is manifested at the lexical level, especially in word-formation area connected with language loans, is reminded. The attention is paid also to the Czech linguists' attitudes of to the issues of internationalization and language "Europeanization". Further so called centripetal and centrifugal tendencies in borrowing language means from foreign languages are mentioned. The next part of the paper is focused on xenophile and xenophobic discourse in borrowing foreign items into the language.
\end{abstract}

Keywords: Czech, economic and cultural levels, globalization tendencies, language internationalization and Europeanization, loan word, word-formation, xenophile and xenophobic discourse in borrowing foreign words.

JEL classification: F60

Doručeno redakci: 3.7.2012; Recenzováno: 11.3.2013; 24.4.2013; 3.5.2013; Schváleno k publikování: 11.9.2013

\section{Introduction}

According to the Oxford English Dictionary, the word globalization was first employed in the publication entitled Towards New Education in 1952, to denote a holistic view of human experience in education (adopted and adapted from http://www.wordreference.com/definition/globalization). However, the concept of globalization may be dated back to the big development of trade and empire across Asia and the Indian Ocean from the 15th century up to now. Nowadays, it is associated especially with economic, industrial, technological, political, informational, ecological, cultural, and last but not least linguistic issues.

In the introduction to the globalization tendencies in Europe and their influence on the languages, namely Czech language, it is suitable to state some widely understood starting points:

- The globalization issues are not only a phenomenon of Czech and the European languages. It concerns unifying and integrating Europe and the whole world.

- Unifying and integrating the world, which covers the term globalization and its processes, reflect tendencies at the political, economic, and cultural level.

- Political, economic, and cultural objectives of the globalizing society should be manifested at the language level as well. 
At this point it is impossible not to mention the fact that it is plausible to meet with various labelling of the world-wide process of unification, integration, and globalization as Gazda states in his work (2003, p. 64).

In the paper we aimed at outlining the most important aspects of globalization and its reflection on the language system. Due to the fact that specific globalization impacts were analyzed in the previous articles (Bobáková, 2007, 2008, 2009), we do not specify them in this contribution.

\section{The globalization reflection on the language}

With respect to the paper objective, it does not seem to be necessary and functional to analyze all the starting points mentioned above. Thus, further the only particular issues of globalization in relation to the language are taken into consideration. In connection with it, it is necessary to remind of so-called internationalization of the language which is manifested namely at the lexical level of the language description - vocabulary, word-formation, loan words and the like. In the Czech linguistic studies, the term internationalization is traditionally related to the term nationalization. Earlier the respected linguist Havránek (1969, p. 44) described antimony in the language, i.e. balancing tendencies in taking over foreign items into the language.

It is important to say that the given subject matter is discussed in many works and articles within the Czech studies. Further, the attention is paid to the crucial ones. The terms of internationalization and nationalization as antagonistic conception of neologisms takeover can be seen from two points of view in the Czech Republic. The first approach comes out from the assumption that nationalization, which may be characterised as preference of domestic expressions, can have purist colouring as Jedlička mentions (1980, p. 185). The other view of nationalization is dealt with in the monograph Slowotwórstwo/Nominacja (wordformation/nomination). In the work nationalization is understood as manifestation of specific features of the national language under conditions of immediate language contact (Martincová 2003 , p. 18). In the framework of this view, the author mentions balancing processes which are manifested at domestic equivalents formation of neologism loans.

In this place we are not going to discuss the types of nationalizing tendencies from orthoepic, orthographic, and morphological level up to denominative and naming level.

It appears that there are certain links between internationalization and balancing tendencies:

- Taking over lexical expressions (internationalization) and the process of forming domestic equivalents (balancing tendencies) indicate that in many cases the domestic equivalents of borrowings do not exist or they do not have the same communicative value. They differ in expressivity and lower frequency of use; however, they can be used as competitive means.

- It has been noticed that the number of internationalization "afixoids and radixoids" is rising (Martincová 2003, p. 22).

It is impossible to forget the fact which is observed by Gazda (2003, p. 64) that the tendencies of internationalization mean the process of rising both the share and functional load of wordforming and lexical items of foreign origin in the lexis of current standard languages. From this point of view, it may be stated that internationalization tendencies help foster the lexis development. 
Let us take into consideration some theoretical background. It may be said that the language task is to follow cognitive and communicative goals. In the course of time, the general conditions of language functioning and operation are changed; thereby some changes in the language may occur. The language change is influenced by various factors. It can be noted that the most important factors include cognitive and communicative aspects on condition that the language system is stable to a certain extent (Fischer, Heike, Peilicke 1987, p. 1).

In addition to the cognitive and communicative aspects, a social dimension of the changes should be considered as well. In this connection, Theobald points out that the language community has to accept and adopt also changes in the language $(1882$, p. 6). At this place, we should remind of some certainly well known facts concerning the language development. The language development is influenced by various factors, some of which are mentioned by Mattheir, i.e.

- articulatory and perceptive apparatus of the man,

- language as a system of signs and norms,

- socio-regional language conditions (Mattheir 1988, pp.720-730).

Single language norms are not exposed to language changes in the same way. The most relevant changes may be observed in lexis, syntax, morphology, and pronunciation. For example, the speaker attempts at simple articulation at the phonic level, and as a result some other changes at the morphological level and lexis may be made. Then the language development endeavours to create disambiguity in morphology and syntax (Lüdke 1988, p. 1632).

It is possible to state that the language in the globalization period is changing under the influence of communication needs. Its determinants are the society, which is changing, and in addition to it, within its framework, individual communicative needs of single speakers. The social dimension of communication may be observed quite evidently in the given development. The essential fact that some changes do not always occur should be noted as well. The process of changes includes two components, a linguistic one, i.e. innovation (origin and formation of a new variant), and a process of realization that means promoting a factual change. The implementation of the process may be influenced by various factors, e.g. changing communication needs, positive assessment of a given expressional form that should be accepted into the domestic system. These processional events are spreading in the social context, and in a certain temporal framework they may be set up. According to Mattheir (1988, p. 1439), the process proceeds in a parallel way in four levels:

A - language proficiency of the individual

1. internal systemic generalization

2. situational and pragmatic generalization

B - social generalization

3. space generalization

4. generalization of a language neologism in the social structure

At first the process proceeds in sporadic cases, i. e. the modified form is used rarely. It is impossible to speak about generalization at this stage. After the extension of the given phenomenon by the means of internal systemic processes, generalization is realized. It should 
be noted at this point that parametrization of the communicative event has already been dealt with by the team of Czech linguists led by J. Kořenský (cf. Kořenský, Hoffmanová, Millerová, Jaklová, 1999). Also it is necessary to point out the communicative model worked out by Patráš. His concept of communicative event comes out from three parameters, i.e. time, space and effort. According to the author, three space vectors influencing the communication course are involved. The effort as the third space vector poses physical and psychical effort that may be measured. In this respect, value, effect, meaning and the like may be concerned (Patráš 2009, p. 106). In connection with the topic of the study, we would like to draw attention to Patraš's model (associated with media communication) and his contribution in the field of communication research in more detail. In our opinion, the study of multidimensionality of communication is relevant in tackling the issues under discussion. It covers aspects such as - time, space, individual social relationship, relation between communication, subject of communication, and intentions and objectives that are perceived and applied by each of the communicants and their emotional world (Patráš, ibid, p. 108). The analyzed issues are dealt with other authors, e.g. Anderson (1973), Thomason (2001) and others.

Concluding, it is essential to make a statement that the origin of new words is characterized by the manifestation of language dynamics determined by extra linguistic aspects.

\section{Attitude of the Czech linguists to the internalization}

With respect to the given topic, it is necessary to mention the well-known Czech linguist Daneš who is interested in the matter and observes that the contact with Europe and the world has initiated not only a vast boom of foreign language competence, but also changed our conception of foreign modification of the Czech language that might not have been accepted so easily in the past (1993, p. 24). From the historic point of view it is understandable, especially for the reason of artificial isolation and closing of the community. However, even in the totalitarian Czechoslovak society, the ideas about the facts that forced interference in the language use and the fight against Anglicisms without stylistic and thematic evaluation do not definitely make a significant contribution to the language culture (Tejnor 1979, p. 212). Bobáková (2006) carried out an interesting research dealing with the attitude of the Czechs to the growing number of Anglicisms in the Czech language in comparison with the situation in Germany.

Insufficient or absent command of a foreign language can lead to two quite contrary tendencies. One may see uncritical taking over vocabulary that should demonstrate the speaker's language competence above all on the one hand. On the other one, missing competence of the English language results in adapting foreign elements into the domestic language system (Bozděchová 1997, p. 278). In the process influence of psychological aspects of the language use can be observed. Fear, concerns about something new and unknown reflects xenophobic tendencies; the evidence for xenophile appears to be internationalization processes not only in the Czech language. Even if the internationalization processes proceed analogically to a certain extent, the clear and distinct influence of cultural and social traditions may be observed as Gazda notices (2003, p. 65). Lotko (1997) states that xenophobic behaviour is usually described in the Czech environment unlike Polish speakers seem to be more tolerant to foreign borrowings. A more detailed study of the matters under discussion was worked out by Daneš (2002).

It is understandable that the given trend may conceal various pitfalls, especially for a certain demographic social stratum which is disadvantaged in some ways, usually by its age. It could 
be disadvantaged also due to the political circumstances. Thus, the low comprehension level becomes the most common subject to critique of foreign elements in the language. English expressions, especially in the journalistic style, do not have to mean the best solution in particular if the cases of trendy expressions are involved. According to Svobodová (1995, p. 137), some other considerations about their stylistic adequacy should be taken into account in more detail. The fact that the tendency of using more neologism is rising leads us to the considerations about the cause for the phenomenon. In our opinion beside political, economic, and cultural aspects which have already been mentioned above, the psychological aspect plays the crucial role within globalization processes. In the following part, we would like to tackle the psychological dimension in more depth.

The use of Anglicism may invoke positive emotions of both the speaker, and listener as well. The speaker's self-confidence is growing, and the positive emotion of the listener is evoked, moreover it can be observed that the feeling of his/her importance and persuasion about his/her own modernity is arising. In this respect, it appears that the attempts at changing cultural and life style, and last but not least cultural values, are made. The typical examples are advertising slogans.

The main tendencies in the development of West Slavonic languages may be summarized into three basic theses as follows:

1. Relative openness of taking over foreign elements is typical of the West Slavonic languages.

2. In the West Slavonic area, the attention of linguists is traditionally focused on cultivating national standard languages and developing nation language culture.

3. Within the West Slavonic languages, domestic and foreign language means exist beside each other at both the levels - the level of macrostructure of language systems, and at the level of single word-forming and lexical-semantic microstructures (Buzászyová, 1997).

From the linguistic point of view, it is necessary to mention positive features of the internationalization of the language, which consists in language enrichment. Thus, it may be said that they contribute to internationalization of communication. It is necessary to state that the extent of internationalization is various within single languages. The biggest differences may be observed in typologically different languages in particular.

Further, in connection with socio-linguistic matters, it should be taken into consideration that globalizing impacts especially of Euro-Atlantic countries bring social relationship release and expanding the lexis, which includes also the negative consequences of the observed tendencies that influence the society life and its members (Mleziva, 1996). Relating to this development the lexis in the discourse of the social group of individuals addicted to drugs may be mentioned.

It may be interesting to add some considerations by Avramová (2005, p. 84) who draws attention to the fact that universalization and hybridization of culture and the way of life in various countries and world regions may be observed in sociolinguistic and culturological perspective. It relates to the universalization process of human values especially in marketing communication, e.g. advertising slogans of the European languages in particular (Bobáková, 2010).

Finally, some other detailed studies tackling the given issues by Bobáková can be appended, e.g. Anglicism investigation in Czech studies (2009), Anglicisms in Czech and German 
(2007) with an analysis and many examples from both the languages, and an article providing an analysis of the contemporary state of English compounds in Czech and German with regard to their formal, morphological and spelling adaptation (2008).

\section{Conclusion}

In conclusion, it may be stated that the current European languages are exposed to the worldwide globalization appearing in the sphere of politics, economy, culture, language, etc. In the linguistic perspective, globalizing tendencies are manifested in internationalization and nationalization of the lexis above all. It may be also stated that xenofilic and xenophobic attempts are a common element in the European languages, and to a greater or lesser extent they reflect the true state of global societies, whose characteristic feature includes universalization and hybridization of the culture and the way of life, and last but not least, universalization of cultural and moral values.

In future it will be interesting to observe and analyze the lexis development in relation to the nationalization and internationalization tendencies with respect to all the language levels.

\section{References}

[1] ANDERSON, J. M., 1974. Structural Aspects of Language Change. London: Longman Group.

[2] AVRAMOVÁ, C., 2005. Internacionalizace a autochtonizace u nových příslušenských názvů (nomina pertinentia) v bulharštině a češtině. In: Internacionalizmy v nové slovní zásobě. Praha: Ústav pro jazyk český, Akademie věd České republiky, pp. 84-92. ISBN 80-86496-11-2.

[3] BOBÁKOVÁ, H-L., 2006. Jazykověda versus veřejnost. Pokus srovnání postojů k anglicizmům v německém a českém jazyce. In: Acta academica karviniensia 2/2006. Karviná: Slezská univerzita v Opavě, OPF v Karviné, pp.16-22. ISSN 1212-415X.

[4] BOBÁKOVÁ, H-L., 2008. Problematika adaptace anglických kompozit v češtině. In: Acta academcia karviniensia 1/2008. Karviná: Slezská univerzita v Opavě, OPF v Karviné, pp.40-46. ISSN 1212-415X.

[5] BOBÁKOVÁ, H-L., 2009. Stav zkoumání anglicizmů v české bohemistice. In: Acta academcia karviniensia 1/2009. Karviná: Slezská univerzita v Opavě, OPF v Karviné, pp.31-36. ISSN 1212-415X.

[6] BOBÁKOVÁ, H-L., 2007. Anglicizmy v českém a německém jazyce. In: Acta academica karviniensia 1/2007. Karviná: Slezská univerzita v Opavě, OPF v Karviné, pp.13-17. ISSN 1212-415X.

[7] BOZDĚCHOVÁ, I., 2003. Nové internacionalizmy v odborném stylu. In: Internacionalizmy v nové slovní zásobě. Praha: Ústav pro jazyk český, Akademie věd České republiky, pp. 42-77. ISBN 80-86496-11-2.

[8] BUZASSYOVÁ, K., 2003. K dimenziám internacionalizacie slovnej zásoby. In: Internacionalizmy v nové slovní zásobě. Slovník příspěvků z konference. Praha 16.-18. června 2003. Praha: UJČ, pp. 5-15. ISBN 80-86496-11-2.

[9] ČMEJRKOVÁ, J. a F. DANEŠ, 1993. Jazyk malého národa. Slovo a slovesnost, 54, pp. 19-29. ISSN 0037-7031. 
[10] DANEŠ, F., 1997. Český jazyk na přelomu tisíciletí. Praha: Academia. ISBN 80-2000617-6.

[11] DANEŠ, F., 2002. Xenismy v současné češtině. In: HLADKÁ, Z. - KARLÍK, P. eds. Čeština - univerzália a specifika 4. Praha: Nakladatelství Lidové noviny, pp. 29-35. ISBN 80-7106-611-7.

[12] GAZDA, J., 2003. Internacionalizační tendence v rozvoji slovní zásoby současných západoslovanských jazyků. In: Internacionalizmy v nové slovní zásobě. Praha: Ústav pro jazyk český, Akademie věd České republiky, pp. 64-73. ISBN 80-86496-11-2.

[13] HAVRÁNEK, B., 1969. Teorie spisovného jazyka. Naše řeč 52, č. 2/3, s. 65-77.

[14] JEDLIČKA, A., 1974. Spisovný jazyk v současné komunikaci. Praha: Univerzita Karlova.

[15] KOŘENSKÝ, J., 1992. K otázce procesuálního pojetí slovní zásoby. Slovo a slovesnost 53, pp. 265-272. ISSN 0037-7031.

[16] KOŘENSKÝ, J. et al., 1987. Komplexní analýza komunikačního procesu a textu: učební text pro výběrové semináře filologických oborů. České Budějovice: Jihočeská univerzita, Pedagogická fakulta. ISBN 80-7040-363-2.

[17] LOTKO, E., 2002. O některých vývojových tendencích v současné slovní zásobě a jejich příčinách na materiálu češtiny, slovenštiny a polštiny. In: Studia Slavica V. Ostrava, pp. 7-21.

[18] MARTINCOVÁ, O. a kol., 1998. Nová slova v češtině 1. Slovník neologizmů. Praha: Academia. ISBN 80-200-0640-0.

[19] MARTINCOVÁ, O. a kol., 2004. Nová slova v češtině 2. Praha: Academia. ISBN 80200-1168-4.

[20] MARTINCOVÁ, V., 2003. Internacionalizace a vyrovnávací tendence. In: Internacionalizmy v nové slovní zásobě. Praha: Ústav pro jazyk český, Akademie věd České republiky, pp. 17-22. ISBN 80-86496-11-2.

[21] MITTER, P., 2006. Kompozice v kontextu současné češtiny. In: Acta Universitatis Purkynianae 127. Studia linguistica. Univerzita J. E. Purkyně v Ústí nad Labem. ISBN 80-7144-811-3.

[22] MLEZIVA, E., 1996. Vliv společenských změn na vznik nových významů a výrazů v českém jazyce. Slovo a slovesnost, 57, pp. 283-296. ISSN 0037-7031.

[23] MRAVINACOVÁ, J., 2003. Anomální kombinace internacionálních morfémů s prvky českého lexika. In: Internacionalizmy v nové slovní zásobě. Praha: Ústav pro jazyk český, Akademie věd České republiky, pp. 126-132. ISBN 80-86496-11-2.

[24] OPAVSKÁ, Z., 2001. Univerbizace a multiverbizace ve slovníku neologiszmů. In: Lexikographica 99, Bratislava: Věda, pp. 146-151. ISSN 0027-8203.

[25] ORGOŇOVÁ, O., 2003. K sémantickej a axiologickej stránke nových internacionalizmov na pozadí interkulturnej konfrontácie, In: Internacionalizmy v nové slovní zásobě. Sborník příspěvků z konference Praha, 16.-18. června 2003, Praha: ÚJČ AV ČR, pp. 193-204. ISBN 80-86496-11-2.

[26] Oxford English Dictionary [online]. [cit. 3rd January 2012]. Accessible from: http://www.wordreference.com/definition/globalization) 
[27] PATRÁŠ, V., 2009. Sociolingvistické aspekty elektronicky podmienenej komunikácie = Sociolinguistic aspects of electronically determined communication. Karviná: Slezská univerzita v Opavě, Obchodně podnikatelská fakulta v Karviné. ISBN 1212-415X.

[28] SIXTOVÁ, H., 2003. K otázce adjektiv ovlivněných angličtinou v češtině a bulharštině. In: Internacionalizmy v nové slovní zásobě. Praha: Ústav pro jazyk český, Akademie věd České republiky, pp. 99-105. ISBN 80-86496-11-2.

[29] SVOBODOVÁ, D., 1999. Anglicizmy v českých publicistických textech - důvody a způsoby jejich užívání. In: Jinakost a cizost v jazyce a literatuře. Ústí nad Labem 1999, pp. 165-169. ISBN 80-7044-240-9.

[30] THOMASON, S. G., 2001. Language Contact. Edinburg: Edinburg University Press. ISBN 0-7486-0719-6.

[31] TICHÁ, Z., 2003. Terapie. (K jednomu internacionálnímu slovotvornému komponentu). In: Internacionalizmy v nové slovní zásobě. Praha: Ústav pro jazyk český, Akademie věd České republiky, pp. 215-219. ISBN 80-86496-11-2.

[32] ULIČNÝ, O., 2000. Dynamika současné spisovné češtiny, stav, problémy, axiologické aspekty. In: Wiener slavistisches Jahrbuch 46, pp. 129-136. ISSN 0084-0041. 